В.М. Оліферук, полковник

НУОУ імені Івана Черняховського

\title{
МОНІТОРИНГ ЯКОСТІ ПРОВЕДЕННЯ ВИКЛАДАЧЕМ НАВЧАЛЬНИХ ЗАНЯТЬ
}

У статті аналізуються сучасні вимоги до професійної компетентності науковопедагогічних працівників, щзо пов'язано з необхідністю підвищення якості освіти та освітньої діяльності. Розглядаються певні проблеми щцодо здійснення моніторингу якості освітнього прочесу у вищих військових навчальних закладах $і$ військово-навчальних підрозділах вищих навчальних закладів. Основну увагу при иъьому приділено моніторингу психолого-педагогічній складової професійної компетентності науково-педагогічних працівників. Запропоновано інструментарій (опитувальник) для оцінювання контролюючими особами якості проведених викладачем навчальних занять.

Ключові слова: якість освіти; якість освітньої діяльності; якість навчальних занять; професійна компетентність викладача; моніторинг якості освіти.

Постановка проблеми. Актуальність проблеми моніторингу якості освіти у вищих навчальних закладах та вищих військових навчальних закладах (ВН3, ВВН3) зумовлена низкою чинників:

подальшою інтеграцією України у світовий і європейський освітній простір;

суттєвими змінами у національній законодавчій базі щодо вищої освіти;

необхідністю реформування i розвитку Збройних Сил України 3 урахуванням сучасних поглядів на застосування військових формувань у збройних конфліктах та досвіду проведення антитерористичної операції (далі - АТО) на сході України;

формуванням нової ідеології стандартів вищої військової освіти на основі компетентнісного, міждисциплінарного підходів i необхідністю впровадження в освітній процес сучасних діагностичних засобів щодо визначення якості освіти та освітньої діяльності;

зростаючими вимогами до випускників ВВНЗ з боку суспільства, керівництва держави, органів військового управління та військ (сил) щодо їх компетентності;

актуалізацією у сфері військової освіти процесу переходу від авторитарних методів навчання до партнерських відносин викладача i слухача (курсанта), індивідуалізації навчання;

новими вимогами до викладачів ВВНЗ, що потребує зміщення акцентів в їх професійній компетентності на практичну складову організації освітнього процесу, а саме прищеплення військовим фахівцям стійких навичок щодо ефективного управління військовими підрозділами в ході бойових дій; протидії застосуванню противником високотехнологічної зброї та нових тактичних схем, протидії інформаційно-психологічному впливу противника тощо.

Аналіз публікацій. Тенденції, проблеми та психолого-педагогічні аспекти моніторингу якості освіти у ВН3, ВВН3 знайшли своє відображення в ряді нормативно-правових актів [1; 2; 3] та наукових праць, що присвячені: фундаменталізації та демократизації освіти ऑii інформатизації та технологізації (А.М. Алексюк, В.І. Бондар, В.В. Давидов, І.П. Підласий); 
формуванню професійної компетентності та педагогічної культури викладача вищого навчального закладу, його самовдосконаленню (Н.С. Красицька, П.Г. Лузан, Л.М. Шовкун, Н.Я. Яремчук, С.Т. Різниченко) [4-8]; моніторингу якості освітнього процесу та його коригуванню (В.І. Андрєєв, А.М. Майоров) [9-11]; професіоналізму науково-педагогічних працівників щодо формування компетентностей у здобувачів вищої військової освіти; оцінюванню якості вищої військової освіти, ії зв'язку з діяльністю військ та аналізу проходження військової служби випускниками ВВНЗ (Ю.І. Приходько, В.М. Телелим) [12].

Метою статті $\epsilon$ розгляд методики оцінювання якості проведення викладачами навчальних занять у системі моніторингових досліджень щодо якості вищої військової освіти.

Виклад основного матеріалу. Освіта, як і будь-який процес або результат діяльності людини, має визначену якість. До якості освіти висуваються відповідні соціальні вимоги. Відтак, цей процес потребує постійного управління на певних методологічних, методичних та організаційних засадах, де чільне місце посідає освітній моніторинг.

Поняття якості освіти визначається Законом України "Про Вищу освіту" як “....рівень здобутих особою знань, умінь, навичок, інших компетентностей, що відображає ії компетентність відповідно до стандартів вищої освіти”. Близьким до нього є поняття якості освітньої діяльності - “...рівень організації освітнього процесу у ВНЗ, що відповідає стандартам вищої освіти, забезпечує здобуття особами якісної вищої освіти та сприяє створенню нових знань”[2].

Отже, головна місія вищого навчального закладу полягає у досягненні визначеного рівня якості освіти, де здійснення моніторингу педагогічної діяльності та аналізу отриманих результатів $\epsilon$ важливими елементами iі забезпечення [3]. Ключову роль у цьому відіграє особистість викладача, його професійна компетентність, фаховість, здатність до розв'язання складних завдань, що пов'язані з організацією освітньої діяльності та створенням відповідного середовища задля оптимального функціонування усіх складових освітнього процесу.

Дослідження загальнонаукових підходів щодо професійної компетентності викладача ВН3, ВВН3 $[4 ; 5 ; 6]$ дозволяють адаптувати їх до особливостей функціонування системи вищої військової освіти з виділенням відповідних складових згаданої компетентності, а саме: науководослідницької, соціально-економічної, загальновійськової та військовоспеціальної, організаційно-управлінської та правової, інформаційнокомунікативної, морально-етичної, психолого-педагогічної.

Психолого-педагогічна компетентність $є$ базовим компонентом професійної компетентності викладача, що передбачає грунтовні знання 3 педагогіки i психології, медико-біологічних аспектів інтелектуальної діяльності; володіння сучасними формами, методами, засобами й технологіями навчання.

Для усвідомлення кожним викладачем рівня сформованості власної професійної компетентності цей рівень має відповідним чином 
відслідковуватися, оцінюватися i визнаватися. Тобто, йдеться про впровадження у педагогічну практику освітнього моніторингу.

Поняття "моніторинг" стосовно вищої військової освіти можна представити як інформаційно-аналітичну складову системи управління освітою або окремими іiі елементами на основі збору, обробки, зберігання i поширення інформації про освітню систему, що дозволяє робити висновки про стан об'єкта (процесу) у будь-який момент часу, прогнозувати його розвиток і сприяти прийняттю та впровадженню відповідних управлінських рішень [6;13].

Тобто, професійна компетентність науково-педагогічних працівників $є$ одним 3 пріоритетних об'єктів постійного моніторингу в системі вищої освіти. Традиції щодо подібних пріоритетів в освіті є усталеними у провідних країнах світу. Корисним, у цьому сенсі, щодо можливого наслідування вітчизняною освітньою системою, $є$ досвід моніторингу педагогічної діяльності викладача вищого навчального закладу, застосовуваний у США. Основними джерелами оцінювання професійної компетентності викладачів у згаданій країні є такі: систематичний рейтинг в тих , хто навчається; оцінка керівника; рейтинг серед колег; оцінювання комітету викладачів; зміст конспектів курсу, що викладається; участь викладача в робочих семінарах; залишкові знання здобувачів вищої освіти; результати іспитів; популярність елективних курсів; думка союзу випускників; самооцінка (підсумкова доповідь викладача) [7].

У такій системі домінує комплексний підхід до оцінювання, в якому задіяно колег, адміністрацію, здобувачів вищої освіти та громадськість. Сукупність цих джерел дає можливість всебічно розглянути діяльність викладача 3 точки зору всіх учасників освітнього процесу i, зокрема, встановити взаємозв' язок між його діяльністю та навчальними результатами тих, хто навчається.

Що стосується оцінювання педагогічної діяльності викладачів вітчизняних ВН3, то тут, здебільшого, використовується метод самооцінки та оцінки керівника (контролюючої особи) [8].

При цьому в оцінюванні педагогічної діяльності викладача контролюючими особами акценти традиційно робилися на кількісних показниках його роботи, якісні - залишалися другорядними.

Відтак, більш пильну увагу варто приділити якісним показникам викладання, що мають відповідати вимогам до професійної компетентності викладача. Для цього може використовуватися відповідний інструментарій (опитувальник), що розробляється зазвичай на критеріальній основі.

Узагальненими показниками в опитувальнику для оцінювання якості проведених викладачем навчальних занять доцільно взяти такі: 1.Організація заняття; 2. Прояв морально-етичних якостей викладача у ході заняття; 3. Прояв дидактичної компетентності викладача у ході заняття.

Критеріiі, що характеризуватимуть прояв кожного iз зазначених показників за результатами проведеного науково-педагогічним працівником окремого навчального заняття, представлено в наведеному експресопитувальнику на прикладі проведення лекційного заняття. 


\section{Е К С П Р Е С - О П И Т У В А Л Ь Н И К}

з оцінювання контролюючими особами якості проведеного науковопедагогічним працівником навчального заняття

(на прикладі лекційного заняття)

Шановні товариші, просимо Вас висловити власну думку щодо якості проведеного викладачем навчального заняття шляхом оцінювання кожного 3 критеріїв представленої таблиці, використовуючи наведену чотирибальну оцінну шкалу. Вам потрібно у стовпчику "Результат оцінювання (Р, бали)" поставити вертикальну риску у будь-якому місці подрібненої оцінної шкали (від балу «2» до балу «5», масштаб - 0,25 бала), що відповідає Вашому сприйняттю прояву кожного 3 представлених критеріїв у ході заняття. При цьому, бал «5»- це еталон прояву критерію (найвищий показник, що тільки можна собі уявити), бал «2»- найнижчий його прояв. Решта - відповідно.

\section{Назва навчальної дисичиліни \\ вписати}

Вид заняття: лекиія, групове, практичне, семінарське заняття тощо (підкреслити або

вписати

Час проведення занять (підкреслити): 1) перша пара; 2) друга пара; 3) третя пара; 4) четверта пара.

\begin{tabular}{|c|c|c|}
\hline $\begin{array}{l}\text { I } \\
\text { № } \\
3 / \Pi\end{array}$ & $\begin{array}{c}\text { Показники та критерії оцінювання якості } \\
\text { проведеного навчального заняття (К) }\end{array}$ & $\begin{array}{c}\text { Результат } \\
\text { оцінювання (Р, бали) }\end{array}$ \\
\hline \multicolumn{3}{|c|}{ 1. Організація заняття: } \\
\hline 1.1 & $\begin{array}{l}\text { Наявність і якість затвердженого план-конспекту } \\
\text { лекції }\end{array}$ & $2 \underset{3}{3} \mathbf{4}^{3}$ \\
\hline 1.2 & $\begin{array}{l}\text { Дотримання визначеної побудови структури лекції } \\
\text { (вступна, основна, заключна частини) }\end{array}$ & $2 \stackrel{3}{3}+{ }^{4}+1+1+1+1$ \\
\hline 1.3 & $\begin{array}{llll}\text { Відповідність } & \text { теми лекції та питань, що } \\
\text { викладаються, } & \text { тематичному } & \text { плану } & \text { вивчення } \\
\text { дисципліни, } & \text { робочої програми } & \text { навчальної } \\
\text { дисципліни } & & & \end{array}$ & $\stackrel{2}{3}+{ }_{1+1}^{4} \mathbf{5}$ \\
\hline 1.4 & $\begin{array}{l}\text { Підтримання дисципліни в ході заняття, уникнення } \\
\text { надмірного адміністрування }\end{array}$ & $\stackrel{2}{1+1+1+1+1+1}$ \\
\hline 1.5 & $\begin{array}{l}\text { Підбиття підсумків заняття, постановка завдань на } \\
\text { самостійну підготовку }\end{array}$ & $\begin{array}{l}4 \\
+1+1+1 \\
\end{array}$ \\
\hline \multicolumn{3}{|c|}{ 2. Прояв морально-етичних якостей викладача у ході заняття: } \\
\hline 2.1 & $\begin{array}{l}\text { Дотримання норм викладацької етики: гідна манера } \\
\text { поведінки, охайність зовнішнього вигляду }\end{array}$ & $2+3$ \\
\hline 2.2 & $\begin{array}{l}\text { Поважне й уважне ставлення викладача як до } \\
\text { окремого слухача (курсанта), так і до колективу } \\
\text { навчальної групи в цілому, без будь-яких упереджень }\end{array}$ & $2 \underset{H}{3} \mathbf{4}_{+1+1+1}^{5}$ \\
\hline 2.3 & $\begin{array}{l}\text { Педагогічний такт викладача: почуття міри, витримка } \\
\text { та врівноваженість }\end{array}$ & $\stackrel{2}{3}+1+1+1+1+1$ \\
\hline 2.4 & $\begin{array}{l}\text { Прояв викладачем толерантності, терпимості до } \\
\text { інших поглядів }\end{array}$ & $2 \stackrel{3}{4}+1+1+1$ \\
\hline
\end{tabular}




\begin{tabular}{|c|c|c|}
\hline $\begin{array}{l}\text { № } \\
\text { 3/ח }\end{array}$ & $\begin{array}{c}\text { Показники та критерії оцінювання якості } \\
\text { проведеного навчального заняття (К) }\end{array}$ & $\begin{array}{c}\text { Результат } \\
\text { оцінювання (Р, бали) }\end{array}$ \\
\hline 2.5 & $\begin{array}{l}\text { Прояв викладачем у ході занять національної } \\
\text { свідомості, патріотизму, їх органічне поєднання із } \\
\text { змістом навчання }\end{array}$ & $\stackrel{2}{H+1+1+} \stackrel{4}{H}^{3}+H^{5}$ \\
\hline \multicolumn{3}{|c|}{ 3. Прояв дидактичної компетентності викладача у ході заняття : } \\
\hline 3.1 & $\begin{array}{l}\text { Визначення цілей заняття, розкриття викладачем } \\
\text { значимості змісту заняття для подальшої професійної } \\
\text { діяльності слухача (курсанта) у військах (силах) }\end{array}$ & $\stackrel{4}{4}+1+1+1$ \\
\hline 3.2 & $\begin{array}{l}\text { Вільне володіння викладачем матеріалом навчальної } \\
\text { дисципліни, конкретного заняття, наявність високих } \\
\text { професійних знань, демонстрація загальної ерудиції }\end{array}$ & $\stackrel{2}{H+1}+\mathfrak{4}^{3}+H^{5}$ \\
\hline 3.3 & $\begin{array}{l}\text { Уміння викладача доступно, зрозуміло викладати } \\
\text { матеріал, роз'яснювати складні моменти, наводити } \\
\text { доречні приклади, виділяти головне, зберігати } \\
\text { логічну послідовність викладання, } \\
\text { переконувати }\end{array}$ & $\begin{array}{r}45 \\
\end{array}$ \\
\hline 3.4 & $\begin{array}{l}\text { Уміння викладача підтримувати зацікавленість } \\
\text { аудиторії в пізнавальній діяльності, створювати } \\
\text { проблемні ситуації під час заняття, спонукати до } \\
\text { дискусії }\end{array}$ & $\stackrel{2}{H}+\stackrel{4}{H}+1+1^{5}$ \\
\hline 3.5 & $\begin{array}{l}\text { Забезпечення викладачем } \\
\text { матеріалу із сз сучасними навчального } \\
\text { військової справи }\end{array}$ & $\stackrel{3}{+}+\stackrel{5}{1+1+1}$ \\
\hline 3.6 & $\begin{array}{l}\text { Створення викладачем мотиваційної основи } \\
\text { (поштовху) для самостійного поглибленого вивчення } \\
\text { навчального матеріалу } \quad \text { заняття, навчальної } \\
\text { дисципліни, спонукання до творчості та ініціативи }\end{array}$ & $3 \stackrel{4}{3}+1+1+1$ \\
\hline 3.7 & $\begin{array}{l}\text { Демонстрація викладачем культури мовлення, чіткої } \\
\text { дикції, оптимального темпу викладання }\end{array}$ & $\stackrel{2}{1+1+1+1+1+1+1}$ \\
\hline 3.8 & $\begin{array}{l}\text { Уміння викладача зняти } \\
\text { аудиторії, почуття гумору }\end{array}$ & $\stackrel{2}{3}+{\stackrel{3}{H}+1+1+H^{5}}^{\mathbf{5}}$ \\
\hline 3.9 & $\begin{array}{l}\text { Обгрунтованість наукових } \\
\text { питань і лекції в цілому }\end{array}$ & $\begin{array}{r}\mathbf{4} \\
+1+1+1+1\end{array}$ \\
\hline 3.10 & $\begin{array}{l}\text { Військово-професійна спрямованість змісту лекції в } \\
\text { контексті підготовки курсантів із спеціальності та } \\
\text { спеціалізації }\end{array}$ & $\begin{array}{l}4 \\
+1+1+1\end{array}$ \\
\hline 3.11 & $\begin{array}{l}\text { Наявність змістовно-логічного зв’язку з навчальними } \\
\text { дисциплінами згідно } 3 \text { структурно-логічною схемою } \\
\text { вивчення навчальної дисципліни }\end{array}$ & $\begin{array}{l}3 \\
+1++1+1+1\end{array}$ \\
\hline 3.12 & $\begin{array}{l}\text { Наочність лекції, застосування демонстрацій, } \\
\text { сучасних технічних засобів навчання і моделюючих } \\
\text { пристроїв на базі комп'ютерної техніки }\end{array}$ & $\stackrel{2}{H}+H_{+}^{4}+H_{+}^{5}$ \\
\hline 3.13 & $\begin{array}{l}\text { Зрозумілість лекції, врахування фактичного рівня } \\
\text { знань курсантів і сприйняття ними наукового змісту } \\
\text { лекції }\end{array}$ & $\stackrel{2}{3}+H_{+1+1+1+1}^{5}$ \\
\hline 3.14 & $\begin{array}{l}\text { Темп лекції забезпечує можливість конспектування } \\
\text { основного змісту лекції }\end{array}$ & $\stackrel{2}{H+1+1+1+1+1}$ \\
\hline
\end{tabular}

Дата заповнення анкети 
Інтегральний показник якості проведеного науково-педагогічним працівником навчального заняття визначається за результатами заповнення експрес-опитувальника. Опитувальник заповнюється контролюючими особами відразу після завершення навчального заняття. Підрахунок результатів опитування проводиться після збору усіх опитувальників за представленим нижче алгоритмом.

В основу підрахунку покладено результати оцінювання, що позначені контролюючими особами на подрібненій (масштаб 0,25 бали) оцінній п’ятибальній шкалі опитувальника відповідною вертикальною рискою (див. Таблицю1).

Далі, результати оцінювання, що проставлені у кожному заповненому опитувальнику по кожному 3 критеріїв $K i$ (де $i$ - № № критеріїв, у даному випадку - від № 1.1 до № 3.14), співвідносяться з балом “5” - еталонним проявом будь-якого критерію за формулою:

$$
K_{i j}=\frac{P_{i j}}{P_{j}^{e m}},(Ж 2.1)
$$

де: $K_{i j}$ - відносний показник прояву $i$-го критерію за результатами оцінювання $j$-ю контролюючою особою;

$P_{i j}$ - абсолютний показник прояву $i$-го критерію, що проставлений в опитувальнику $j$-ї контролюючої особи - від балу “2” до балу “5”; $P_{i}^{e m}$ еталонний показник прояву $i$-го критерію - (бал “5”).

Дана процедура призначена для переходу від абсолютних (бальних) показників до відносних. При цьому, прояв критерію, оцінений балом “2" прирівнюється до “0”. Наприклад, якщо критерій № 3.7 (див. Таблицю 1) "Демонстрація культури мовлення, чіткої дикції, оптимального темпу викладання” оцінено на шкалі у 3,5 бали, то відносний показник № $3.7=3,5$ : $5=0,7$. А якщо, припустимо, критерій № 1.5 - "Підбиття підсумків заняття, постановка завдань на самостійну підготовку " оцінено у 2,0 бали, то критерій № $1.5=0: 5=0$. Аналогічно визначається прояв у ході занять усіх інших критеріїв. в основу інтегрального показника $-K_{\Sigma}$ якості проведеного викладачем навчального заняття за результатами його оцінювання контролюючою особою покладено підрахунок прояву окремих критеріїв у кожній $з$ груп критеріїв. Відтак, необхідно визначити усереднений відносний показник прояву $i$-х критеріїв у кожній з груп критеріїв.

$$
K_{\sum} \mathrm{j}_{=} \frac{\sum_{i=1}^{n} K_{i}}{n}
$$

де: $K_{\Sigma} j-$ інтегральний показник якості проведеного заняття за оцінкою j-ї контролюючої особи; $\boldsymbol{K i}$-відносний показник прояву і-х критеріїв; $\boldsymbol{n}$ загальна кількість критеріїв в опитувальнику. 
Таким чином, інтегральний показник якості проведеного навчального заняття $0 \leq K_{\Sigma} \leq 1$. Перехід на відносні показники технологічно виправданий для більш зручного проведення аналізу отриманих даних. Наприклад $K_{\Sigma}=$ 0.75 або $75 \%$ від еталонного показника "1". Втрати склали $25 \%$, які можна відслідковувати по кожному з критеріїв . Аналогічно визначається показник прояву i-х критеріїв для кожної з груп критеріїв (дивись Таблицю 1).

Аналіз отриманих даних дає змогу визначити як позитиви, так і певні вади за результатами проведення заняття викладачем, прийняти відповідні управлінські рішення щодо оптимізації освітнього процесу, спланувати проведення відповідних заходів 3 наукової та навчально-методичної роботи.

Висновки. Таким чином, моніторинг якості освіти та освітньої діяльності у ВВНЗ являє собою актуальну, багатоаспектну педагогічну проблему, що потребує невідкладного розв'язання у теорії та практиці вищої та вищої військової шкіл. Особливої значущості дана проблема набула у зв'язку із суттєвими змінами у національній законодавчій базі щодо вищої освіти; необхідністю реформування і розвитку Збройних Сил України 3 урахуванням сучасних поглядів на застосування військових формувань у збройних конфліктах та досвіду АТО; необхідністю впровадження в освітній процес сучасних підходів до діагностики якості освітньої діяльності; зростаючими вимогами до науково-педагогічних працівників та випускників ВВНЗ. Важливим компонентом моніторингу якості освіти у ВВН3 $є$ забезпечення зворотних зв'язків, особливо, що стосується оцінювання якості проведення навчальних занять як основної складової освітнього процесу. У статті розглядаються деякі підходи до практичного вирішення даної проблеми. Подальше їі розроблення сприятиме процесу управління якістю освіти та освітньої діяльності ВВНЗ.

\section{ЛІТЕРАТУРА}

1. Указ Президента України від 26 травня 2015 року № 287/2015 “Про рішення Ради національної безпеки і оборони України від 6 травня 2015 року “Про Стратегію національної безпеки України".

2. Закон України "Про Вищу освіту" від 1 липня 2014 року.

3. Указ Президента України від 25 червня 2013 року № 344/2013 “Про Національну стратегію розвитку освіти в Україні на період до 2021 року ".

4. Яремчук Н.Я. Педагогічна творчість як складова професійно-педагогічної культури викладача вищої школи / Н. Яремчук // Вісник Львівського університету. Серія: Педагогіка. - 2009. - Вип. 25. - Ч.1. - С. 242-249.

5. Шовкун Л.М., Лузан П.Г. Професійна компетентність викладача вищого аграрного навчального закладу та ії оцінювання / П.Г. Лузан, Л.М. Шовкун // Проблеми інженернопедагогічної освіти: [зб. наук. пр.] - Х.: УІПА, 2006. - Вип. 14-15. - С.226-234.

6.Зельнииький $A$ M. Професійна компетентність викладача вищого військового навчального закладу / А.М. Зельницький, О.О. Мітягін, О.О. Пашкова // Вісник НУОУ. 2013. - № 2. - С. 84-95.

7. Різниченко C.T. До проблеми атестації науково-педагогічних кадрів в США / С.T. Різниченко // Теоретичні питання освіти і виховання: Збірник наукових праць. Випуск 9. К.: Вид. центр КДЛУ, 2000. - С. 112-116. 
8. Красищька Н.С. Основні складові професійної компетентності викладача вищого навчального закладу / Н.С. Красицька // Науковий журнал “Вісник ДонНУЕТ”. - 2010. №2 (46). - С. 198-205.

9. Андреев В.И. Проблемы педагогического мониторинга качества образования / В.И. Андреев //Известия Российской Академии Наук. - 2001. - № 1. - С. 37.

10. Майоров А.Н. Мониторинг в образовании. Книга 1 /А.Н.Майоров. - Спб.: Издательство “Образование-Культура”, 1998. - 344c.

11. Зельницький А.М. Вища військова освіта - проблема гарантування якості /Зельницький А.М. // Вісник НАОУ. - 2012. - № 1 (26). - С. 23-25.

12. Телелим В.М. Моніторинг в системі військової освіти / Ю.І. Приходько // Збірник наукових праць “Військова освіта”. - 2014. - № 1 (29). - С. 3-13.

13. Моніторинг якості підготовки військових фахівців у вищих військових навчальних закладах та військових навчальних підрозділах вищих навчальних закладів Збройних Сил України: наук.-метод. посібник. - / А. М. Алімпієв, І.В. Толок, М. І. Литвиненко та ін.; під заг. ред. І. В. Толока. - Х. : ХНУПС, 2017. - 244 с.

В.Н. Олиферук, полковник

НУОУ имени Ивана Черняховского

\section{МОНИТОРИНГ КАЧЕСТВА ПРОВЕДЕНИЯ ПРЕПОДАВАТЕЛЕМ УЧЕБНЫХ ЗАНЯТИЙ}

В статье анализируются современные требования $\kappa$ профессиональной компетентности преподавателей, что связано с необходимостью повышения качества образования и образовательной деятельности. Рассматриваются некоторые проблемы осуществления мониторинга качества образовательного процесса в высших военноучебных заведениях. Особое внимание при этом уделено мониторингу психологопедагогической составляющей профессиональной компетентности преподавателя. Предложен инструментарий (опросник) по оцениванию качества проведения преподавателем отдельных видов учебных занятий.

Ключевые слова: качество образования; качество образовательной деятельности; качество учебных занятий; профессиональная компетентность преподавателя; мониторинг качества образования.

V.N. Oliferuk, colonel

NDUUnamed after Ivan Chernyahovskiy

\section{MONITORING THE QUALITY OF TEACHER TRAINING SESSIONS}

The article analyses modern requirements to professional competence of teachers, which is associated with the need to improve the quality of education and educational activities. Discusses some of the problems of monitoring the quality of educational process in higher military educational institutions. Special attention is paid to the monitoring of the psychopedagogical component of teacher's professional competence and the instruments (questionnaire) for assessment of the quality of teacher individual types of lessons.

Key words: quality of education; quality of educational activities; quality training; the professional competence of the teacher; monitoring the quality of education. 